\title{
ANALISIS FAKTOR PENYEBAB PESERTA DIDIK DENGAN IQ TINGGI MEMPEROLEH HASIL BELAJAR MATEMATIKA RENDAH
}

\author{
Rahmita Nurul Muthmainnah ${ }^{1 *}$ dan Mega Purnamasari ${ }^{2)}$ \\ ${ }^{1,2)}$ Pendidikan Matematika, Fakultas Ilmu Pendidikan, Universitas Muhammadiyah Jakarta \\ Jl. KH. Ahmad Dahlan Cirendeu, 15419 \\ *rahmita.nurul@umj.ac.id
}

\begin{abstract}
Abstrak
Penelitian ini merupakan penelitian studi kasus di SMP Al Ghazali Gunung Sindur yang bertujuan untuk mendeskripsikan faktor-faktor penyebab peserta didik dengan IQ tinggi memperoleh hasil belajar matematika rendah (underachiever). Metode penelitian yang dilakukan dalam penelitian ini adalah deskriptif kualitatif. Subjek penelitian ini berjumlah adalah siswa kelas VIII-3 dengan skor IQ superior (di atas 120) dan hasil belajar matematika dibawah KKM. Teknik pengumpulan data dilakukan dengan menggunakan angket dan wawancara siswa. Hasil penelitian menunjukan terdapat 3 subjek $(A, B$, dan $C)$ dengan $I Q$ superior dengan haril belajar di bawah KKM. Penyebab utama ketiga subjek menjadi siswa underachiever karena faktor kepribadian individu. Subjek A merasa masa bodoh dengan pelajaran matematika, tidak teliti, serta tidak mengecek kembali jawaban matematika yang telah dikerjakan sehingga hal tersebut menyebabkan kesalahan dalam menjawab soal. Subjek $B$ tidak mempunyai rasa percaya diri dan ragu dalam menjawab pertanyaan. Sedangkan subjek $C$ tidak mempunyai rasa percaya diri dan cenderung pesimis dalam pelajaran matematika, sering menyalin jawaban teman serta tidak serius dalam menjawab pertanyaan.
\end{abstract}

Kata Kunci: IQ, underachiever, matematika.

\section{PENDAHULUAN}

Pembelajaran merupakan proses interaksi antara guru dengan peserta didik dimana terdapat komunikasi timbal balik dalam situasi edukatif untuk mencapai tujuan yang ditetapkan (Rustaman, 2001). Dalam UU Sisdiknas No 20 Tahun 2003 dijelaskan bahwa pembelajaran adalah proses interaksi antara guru dengan peserta didik dan sumber belajar dalam lingkup belajar.

Dalam proses pembelajaran, hasil belajar menjadi salah satu penentu keberhasilan. Hasil belajar yang baik menentukan berhasilnya proses pembelajaran tersebut, begitu pula sebaliknya, hasil belajar yang kurang baik menjadi tolak ukur ketidakberhasilan proses belajar. Selain sebagai penentu keberhasilan 
suatu proses pembelajaran, hasil belajar juga menjadi tolak ukur untuk menentukan tingkat keberhasilan peserta didik dalam memahami suatu materi pelajaran yaitu dengan menggunakan instrumen tes dan dinyakatan dalam bentuk nilai akhir.

Kecerdasan atau intelegensia dapat diartikan sebagai keseluruhan kemampuan individu untuk memperoleh pengetahuan, menguasainya, serta mempraktikannya dalam suatu masalah (Kokasih dan Sumarna, 2013). Kecerdasan sering juga didefinisikan sebagai kemampuan mental umum untuk belajar dan menerapkan pengetahuan dalam memanipulasi lingkungan, serta kemampuan untuk berfikir abstrak (Bainbridge dalam Yaumi dan Ibrahim, 2013). Secara garis besar kecerdasan merupakan suatu kemampuan mental yang melibatkan proses berpikir manusia secara rasional. Kecerdasan tidak dapat diamati secara langsung, melainkan harus disimpulkan dari berbagai tindakan nyata yang merupakan manifestasi dari proses berpikir rasional tersebut. Kecerdasan tecermin dari tindakan yang terarah pada penyesuaian diri terhadap lingkungan serta pemecahan masalah yang timbul daripadanya.

Inteligensi atau kecerdasan ditetapkan dalam ukuran yang disebut Intelligence Quotient (IQ). Untuk mengetahui tingkat kecerdasan seseorang dapat dilakukan dengan menggunakan suatu instrumen test yang biasa kita kenal dengan nama Tes IQ yang pertama kali dikembangkan oleh ahli psikologi Prancis Alfred Binet pada tahun 1881. Ukuran IQ indeks relatif kecerdasan anak setelah ia dibandingkan dengan anakanak lain yang seusia (Suryabrata, 2002; J.P. Chaplin dalam Sutriningsih, 2017). Intelligence Quotient (IQ) merupakan suatu indeks tingkat relatif kecerdasan anak, setelah ia dibandingkan dengan anak-anak Q lain yang seusia. Menurut Binet intelegensi anak akan terus bertambah sampai umur 15 tahun, di atas umur 15 yang bertambah hanyalah pengetahuannya saja.

Hasil akhir dari tes tersebut berupa angka yang kemudian diklasifikasikan ke dalam tingkatan kecerdasan seseorang. Klasifikasi IQ oleh Woodworth dan Marquis sebagai berikut:

Tabel 1 Klasifikasi Kecerdasan IQ

\begin{tabular}{|c|c|}
\hline Skor IQ & Kategori \\
\hline $140 \leq \mathrm{IQ}$ & $\begin{array}{ll}\text { Luar } & \text { Biasa } \\
\text { (genius) } & \\
\end{array}$ \\
\hline $120 \leq \mathrm{IQ}<140$ & $\begin{array}{l}\text { Cerdas Sekali } \\
\text { (very superior) }\end{array}$ \\
\hline $110 \leq \mathrm{IQ}<120$ & $\begin{array}{l}\text { Cerdas } \\
\text { (superior) }\end{array}$ \\
\hline $90 \leq \mathrm{IQ}<110$ & $\begin{array}{l}\text { Sedang } \\
\text { (average) }\end{array}$ \\
\hline $80 \leq \mathrm{IQ}<90$ & $\begin{array}{l}\text { Bodoh } \\
(\text { dull average })\end{array}$ \\
\hline $70 \leq \mathrm{IQ}<80$ & $\begin{array}{l}\text { Perbatasan } \\
\text { (border line) }\end{array}$ \\
\hline $50 \leq \mathrm{IQ}<70$ & $\begin{array}{l}\text { Debil } \\
\text { (moron) }\end{array}$ \\
\hline $30 \leq \mathrm{IQ}<50$ & $\begin{array}{l}\text { Ambisil } \\
(\text { embicile })\end{array}$ \\
\hline IQ $<30$ & $\begin{array}{l}\text { Idiot } \\
\text { (ideot) }\end{array}$ \\
\hline
\end{tabular}

Sumber : (Suryabrata, 2002)

Intelegensi dan prestasi belajar dalam pendidikan merupakan dua hal yang saling keterkaitan satu sama lain. Di mana biasanya individu yang memiliki intelegensi yang tinggi akan cenderung memiliki prestasi yang membanggakan di kelasnya (Djamarah, 2011). Namun kenyataannya fakta dilapangan menunjukkan bahwa masih terdapat anak dengan intelegensi tinggi yang mendapatkan hasil belajar rendah atau biasa disebut dengan underachiever. 
Underachiever adalah istilah yang digunakan untuk individu atau seseorang yang prestasi belajarnya berada di bawah kemampuan anak sesungguhnya atau rendah (Sulthon, 2014; Rahmawati, 2013) Hal ini bisanya terjadi pada anak-anak yang memiliki tingkat intelegensi yang tinggi namun prestasinya di sekolah berada di bawah performance anak tersebut.

Munculnya underachiever tidak serta merta dengan sendirinya, melainkan ada beberapa faktor yang berpotensi menjadi penyebabnya (Rahmawati, 2013). Shufiyanti, dkk (dalam Sutriningsih, 2017) mengkategorikan faktor penyebab seseorang mengalami underachiever ke dalam dua kelompok yaitu: (1) Faktor internal yang meliputi, motivasi (tidak menyadari potensi yang dimiliki, target prestasi yang terlalu rendah, takut mengalami kegagalan dan kesuksesan, terlalu sensitif terhadap penilaian orang), kondisi fisik, kepribadian individu (perfectionisme, terlalu sensitif, tidak berdaya guna dalam keterampilan sosial, malu dan rendah diri karena berbeda dengan siswa lain, tidak percaya diri, dan terlalu banyak kegiatan), pembebanan (padatnya materi-materi sekolah hingga mencapai delapan jam mata pelajaran sehari, ditambah lagi dengan tugas-tugas yang banyak dan banyaknya kegiatan ekstrakulikuler); (2) Faktor eksternal meliputi, faktor keluarga (kurangnya penghargaan dan ketidakpedulian orang tua terhadap belajar dan prestasi anak, tuntutan orang tua terhadap target prestasi anak yang terlalu tinggi, kurangnya perhatian terhadap potensi anak, dan status sosial ekonomi), sekolah (kurangnya dukungan terhadap keberhasilan akademik, kurikulum tidak sesuai dengan kondisi siswa, lingkungan kelas yang tidak kondusif, kurang tepatnya pemilihan strategi belajar dan lingkungan tempat tinggal (tuntutan lingkungan terhadap prestasi anak, dan lingkungan yang tidak mendukung pendidikan).

\section{METODE PENELITIAN}

Penelitian ini dilaksanakan di SMP Al Ghazali Gunung Sindur. Penelitian ini menggunakan metode penelitian deskriptif kualitatif. Subjek dalam penelitian ini adalah tiga orang siswa kelas VIII-3 Tahun Ajaran 2017/2018 dengan IQ masing-masing siswa 120 (klasifikasi Cerdas Sekali) yang memperoleh hasil belajar matematika rendah atau di bawah KKM (kurang dari 70).

Teknik pengumpulan data menggunakan angket dan wawancara. Kemudian, data yang telah dikumpulkan ditriangulasikan menggunakan triangulasi teknik dan dianalisis menggunakan analisis data Model Miles dan Huberman. Model Miles dan Huberman memiliki aktivitas yang dilakukan, yaitu: pengumpulan data, reduksi data, display data, dan verifikasi / penarikan kesimpulan.

\section{HASIL DAN PEMBAHASAN}

Berikut skor IQ dan nilai hasil belajar yang diperoleh dari hasil Penilaian Tengah Semester (PTS) dari ketiga subjek penelitian:

Tabel 2 Skor IQ dan Hasil Belajar Subjek

\begin{tabular}{lllll}
\hline No & Subjek & $\begin{array}{l}\text { Skor } \\
\text { IQ }\end{array}$ & Klasifikasi & PTS \\
\hline 1 & $\begin{array}{l}\text { Subjek } \\
\text { A }\end{array}$ & 120 & $\begin{array}{l}\text { Cerdas } \\
\text { Sekali }\end{array}$ & 44 \\
\hline 2 & $\begin{array}{l}\text { Subjek } \\
\text { B }\end{array}$ & 120 & $\begin{array}{l}\text { Cerdas } \\
\text { Sekali }\end{array}$ & 32 \\
\hline 3 & $\begin{array}{l}\text { Subjek } \\
\text { C }\end{array}$ & 120 & $\begin{array}{l}\text { Cerdas } \\
\text { Sekali }\end{array}$ & 40 \\
\hline
\end{tabular}

Faktor utama subjek A dengan IQ tinggi memperoleh hasil belajar rendah disebabkan oleh faktor internal yaitu 
kepribadian individu. Selama proses wawancara terkait perfeksionisme diketahui bahwa subjek A adalah siswa yang teliti serta hati-hati dalam melakukan suatu hal tetapi tidak dalam mengerjakan soal matematika. Subjek A cenderung meremehkan dan masa bodoh dengan nilai matematika, tidak peduli hasil pekerjaannya benar atau salah ataupun tidak sesuai dengan jawaban sesungguhnya. Dalam menggunakan rumus matematika, subjek A juga terlihat tidak teliti. Faktor kedua yaitu faktor pembebanan. Dari data dilapangan, dapat diketahui bahwa subjek A tidak mengikuti pelajaran matematika pada hari Sabtu dikarenakan mendapat tugas yang mengakibatkan tidak dapat mengikuti pembelajaran di sekolah maupun kegiatan di pondok pesantren. Berdasarkan data yang diperoleh diketahui bahwa subjek A setidaknya 6 kali tidak mengikuti pelajaran matematika untuk mengerjakan tugas dari pondok pesantren. Faktor ketiga adalah motivasi, subyek A terlihat cenderung kurang meminati pelajaran matematika serta kurang termotivasi dalam belajar matematika hal ini dikarenakan ia merasa matematika adalah pelajaran yang susah, ia lebih menyukai pelajaran yang sifatnya menghafal dibandingkan dengan menghitung. Dibandingkan dengan pelajaran matematika, subjek A lebih memprioritaskan pelajaran pondok pesantren serta mata pelajaran umum yang seperti IPS, Penjaskes, dan Bahasa Arab.

Faktor utama subjek B dengan IQ tinggi memperoleh hasil belajar matematika rendah disebabkan oleh faktor internal yaitu kepribadian individu. Selama proses wawancara terkait rasa percaya diri diketahui bahwa subjek B memiliki sifat kurang percaya diri dan ragu untuk bertindak. Dalam pelajaran matematika subjek B sering merasa takut salah dalam menjawab pertanyaan, terutama saat guru mengajukan pertanyaan di kelas, subjek B cenderung menyuruh temannya untuk menjawab. Setelah pertanyaan tersebut terjawab sering muncul penyesalan dalam diri subjek B dikarenakan pada dasarnya ia mengetahui jawaban dari pertanyaan tersebut. Faktor kedua penyebab subyek B dengan IQ tinggi memperoleh hasil belajar matematika rendah adalah terkait motivasi. Subyek B berpendapat bahwa matematika adalah mata pelajaran yang susah. Subjek B lebih menyukai pelajaran yang sifatnya menghafal dibandingkan dengan menghitung, sehingga ia kurang termotivasi dalam belajar matematika. Sama halnya dengan subjek A, subjek B cenderung memprioritaskan pelajaran pondok pesantren dan mata pelajaran umum yang ia senangi seperti Bahasa Indonesia, Bahasa Arab, dan Penjaskes. Faktor ketiga yaitu faktor pembebanan. Tugas yang didapatkan subjek B dalam seminggu adalah piket asrama sebanyak 2 kali, dan jaga malam sebanyak 4 kali, dimana tugas tersebut mengakibatkan ia meninggalkan mata pelajaran matematika.

Faktor utama subjek C dengan IQ tinggi memperoleh hasil belajar matematika rendah disebabkan oleh faktor internal yaitu kepribadian individu. Subjek C termasuk anak yang tidak percaya diri dalam menjawab soal-soal matematika sehingga ia menjawab soal-soal matematika tersebut secara asal-asalan atau ia memilih untuk menyalin jawaban teman dibandingkan harus menuliskan jawabannya sendiri. Saat guru memberikan pertanyaan di kelas, subjek $\mathrm{C}$ cenderung akan diam saja tidak memikirkan jawaban tersebut karena ia sudah merasa pesimis akan salah atas jawaban yang dikerjakannya. Selama proses wawancara ia menunjukkan ketidakinginan untuk ditanya terkait soal-soal matematika 
dikarenakan merasa pusing serta tidak suka dengan perhitungan. Faktor kedua, mengenai motivasi belajar. Sejalan dengan kedua subjek sebelumnya, subyek $\mathrm{C}$ juga lebih menyukai menghafal dibandingkan menghitung. Subjek C cenderung tidak meminati pelajaran matematika serta tidak memiliki motivasi dalam belajar matematika hal ini dikarenakan ia merasa matematika adalah pelajaran yang paling susah dibanding pelajaran yang lain. Oleh karenanya, subjek $\mathrm{C}$ lebih memprioritaskan pelajaran pondok pesantren dan mata pelajaran umum yang ia senangi seperti Prakarya, Seni Budaya, dan Penjaskes. Faktor ketiga, adalah faktor pembebanan. Beban piket serta tugas asrama mengakibatkan subjek $\mathrm{C}$ sering tidak bisa mengikuti pembelajaran di kelas khususnya mata pelajaran matematika.

\section{SIMPULAN}

Berdasarkan hasil dan pembahasan yang telah diuraikan sebelumnya, dapat diambil ditarik kesimpulan ketiga subjek (A, B, dan C) termasuk dalam kategori underachiever, yaitu anak dengan IQ tinggi namun mendapatkan hasil belajar (matematika) rendah. Adapun faktor utama penyebab ketiga subjek dengan IQ tinggi tersebut memperoleh hasil belajar matematika rendah disebabkan oleh factor internal yaitu kepribadian individu.

Subjek A dengan skor IQ 120 dan memperoleh nilai PTS 44 termasuk anak yang perfeksionis dalam segala hal selain matematika, dimana ia cenderung masa bodoh dengan mata pelajaran matematika, tidak teliti, serta tidak mau mengecek kembali jawaban matematika yang telah ia kerjakan sehingga hal ini membuat ia sering salah dalam menjawab soal dikarenakan ketidak telitiannya tersebut.

Subjek B dengan skor IQ 120 dan memperoleh nilai PTS 32 termasuk anak yang tidak mempunyai rasa percaya diri yang terlihat dari sering merasa ragu dalam menjawab pertanyaan / soal matematika padahal ia mempunyai potensi untuk berprestasi dan memperoleh nilai yang lebih baik.

Subjek C dengan skor IQ 120 dan memperoleh nilai PTS 40 tidak mempunyai rasa percaya diri dan cenderung pesimis dalam pelajaran matematika, lebih memilih untuk menyalin jawaban teman serta cenderung asal-asalan dalam menjawab soal-soal matematika.

\section{DAFTAR PUSTAKA}

Djamarah, S.B. 2011. Psikologi Belajar. Jakarta: Rineka Cipta.

Kosasih, N dan Dede, S. 2013. Pembelajaran Quantum dan Optimalisasi Kecerdasan. Bandung: Alfabeta.

Rachmawati, R. 2013. "Bimbingan dan Konseling Untuk Anak Underachiever”. Prakdikma Jurnal Psikologi Pendidikan dan Konselling ISSN 1907-297X.

Rustaman, N. 2001. Ilmu dan Aplikasi Pendidikan. Bandung: Inperial Bakti Utama.

Sulthon. 2014. "Mengenal Anak Undrachiever dan Upaya Peningktan Prestasi Belajarnya di Madrasah Ibtidaiyah (MI)". ELEMENTARY Vol 2, No. 1. 
FIBONACCI : Jurnal Pendidikan Matematika dan Matematika

Volume 5 No. 1 Bulan Juni Tahun 2019

Suryabrata, S. 2002. Psikologi Pendidikan. Jakarta: PT Raja Grafindo Persada.

Sutriningsih, N. 2017. "Penyebab Siswa Underachiever Dalam Pembelajaran Matematika". Jurnal Edumath, Vol 3 No. 2 ISSN 2356-2056.

Yaumi, M dan Nurdin, I. 2013. Pembelajaran Berbasis Kecerdasan Jamak (Multiple Intelligences) Mengidentifikasi dan Mengembangkan Multitalenta Anak. Jakarta: Kencana Prenadamedia Group. 